\title{
Genes Associated with Alzheimer's Disease in Post-Ischemic Brain Neurodegeneration
}

\author{
Ryszard Pluta • Marzena Ułamek-Kozioł \\ Laboratory of Ischemic and Neurodegenerative Brain Research, Mossakowski Medical \\ Research Institute, Polish Academy of Sciences, Warsaw, Poland
}

Author for correspondence: Ryszard Pluta, Laboratory of Ischemic and Neurodegenerative Brain Research, Mossakowski Medical Research Institute, Polish Academy of Sciences, Warsaw, Poland. Email: pluta@imdik.pan.pl

Cite this chapter as: Pluta R, Ułamek-Kozioł M. Genes Associated with Alzheimer's Disease in Post-Ischemic Brain Neurodegeneration. In: Pluta R, editor. Cerebral Ischemia. Brisbane (AU): Exon Publications; 2021. Online first Aug 31.

Doi: https://doi.org/10.36255/exonpublications.cerebralischemia.2021.genes

\begin{abstract}
Recent studies have highlighted the role of focal or total ischemia in the development of post-ischemic brain neurodegeneration. However, despite extensive research, the exact mechanism(s) by which ischemia contributes to brain neurodegeneration remains unclear. Therefore, understanding the mechanisms of post-ischemic neurodegeneration of the brain may allow us to develop effective therapies for the prevention and treatment of neurodegenerative diseases. This chapter summarizes the latest research into post-ischemic signaling associated with the development of post-ischemic brain neurodegeneration with Alzheimer's disease-type neuropathology and dementia. We focus mainly on the genes associated with Alzheimer's disease, which play an important role in the development of post-ischemic brain neurodegeneration. Also, the potential role of ischemic factors as new therapeutic targets and prognostic markers in patients with neurodegenerative diseases such as Alzheimer's disease is discussed.
\end{abstract}

In: Cerebral Ischemia. Pluta R (Editor). Exon Publications, Brisbane, Australia. ISBN: 978-0-6450017-9-2; Doi: https://doi.org/10.36255/exonpublications. cerebralischemia.2021

Copyright: The Authors.

License: This open access article is licenced under Creative Commons Attribution-NonCommercial 4.0 International (CC BY-NC 4.0) https://creativecommons.org/licenses/by-nc/4.0/ 
Keywords: Alzheimer's disease; amyloid; brain ischemia; hippocampus; tau protein

\section{INTRODUCTION}

Post-ischemic brain neurodegeneration is a leading cause of death and disability worldwide (1). The incidence of the condition is increasing as the world's population ages. The prevalence of brain ischemia in the elderly is high and the risk is 1 in 3 (2). Post-ischemic brain neurodegeneration is a serious neurological problem that significantly affects the quality of life of patients and causes a heavy burden on the economy and society. Currently, about 17 million people suffer from brain ischemia each year, of which 6 million die $(3,4)$. Worldwide, it is estimated that the number of post-ischemic patients is currently around 33 million $(3,4)$. The number of cases will increase to 77 million by 2030 $(3,4)$. If the trend of ischemic stroke continues, there will be about 12 million deaths by 2030, 70 million will survive a stroke, and over 200 million disabilityadjusted life years will be recorded worldwide annually (4). In 2010, the annual cost of caring for stroke patients in Europe was around $€ 64$ billion (4). In the $\mathrm{UK}$, treating stroke and loss of productivity results in a social cost of $£ 8.9$ billion per year, with care costs accounting for about $5 \%$ of the total cost of the national healthcare system (5).

Symptoms of post-ischemic brain neurodegeneration include memory loss, cognitive impairment, and eventually the development of dementia (6-8). Despite the wealth of research on brain ischemia over the past decade, there is no known effective treatment that would prevent or slow the progression of post-ischemic neurodegeneration. Therefore, a deeper understanding of the cellular and molecular mechanisms underlying post-ischemic neurodegeneration will be essential for the development of new therapeutic targets. There is growing interest in studying the potential contribution of ischemic factors to neuronal function and survival, and in identifying potential targets for the development of therapeutic and diagnostic strategies, as there is ample evidence for the influence of ischemia on the development of neurodegenerative diseases such as Alzheimer's disease (7, 9-13).

Post-ischemic neuropathology shows extensive neuronal death in the hippocampus and cortex (14-18), with accumulation of amyloid deposits such as diffuse and senile plaques $(15,19-29)$ and an increase in total tau protein (30) with its hyperphosphorylation (31), resulting in the development of a paired helical filaments (32), neurofibrillary tangle-like $(33,34)$ and finally, neurofibrillary tangles $(35,36)$. Post-ischemic brain studies have shown the disintegration of the blood-brain barrier (37-41) and the accumulation of toxic blood-derived proteins in the central nervous system, such as amyloid and tau protein (42-59), which in turn probably leads to progressive and irreversible damage to the entire brain. This then leads to neurodegeneration and ischemic death of neurons directly mediated by excitotoxicity (60) and indirectly by the neurotoxicity of folding proteins. As a result of the dysfunction of the blood-brain barrier, immune cells enter the brain and cause inflammation of the nervous system, which is an important factor in the development of neurodegenerative diseases, including 
post-ischemic neurodegeneration of the brain $(61,62)$. On the other hand, the increased level of amyloid in the post-ischemic brain causes the accumulation of amyloid not only in the brain tissue but also in the vessel wall, causing the development of cerebral amyloid angiopathy $(15,63)$. Reduction in the length of cerebral vessels post-ischemia, or impaired cerebral blood flow in the brain as a result of vasoconstriction (64), and/or the development of cerebral amyloid angiopathy $(15,63)$, limits the transport of energy substrates, hampers the supply of oxygen and nutrients to the brain through the blood-brain barrier, and reduces the clearance of potential neurotoxins from the brain, such as amyloid (63). In postischemic neurodegeneration, a lack of acetylcholine in the brain, especially in the hippocampus, has been found; acetylcholine is a neurotransmitter that plays a key role in neuronal signaling and memory formation, and its lack is a known cause of dementia (65).

Brain ischemia-reperfusion injury shows signs of progressive neurodegeneration that develops slowly over a long period of time during recirculation (15). Brain autopsy 1-2 years after experimental ischemia revealed hydrocephalus with widening of the ventricles and subarachnoid space $(14,15,66,67)$. This was accompanied by complete atrophy of the hippocampus with a very narrow brain cortex $(14,15,17,18,66-68)$. The ultimate consequence of this phenomenon was the development of dementia in experimental and clinical cases after transient and reversible brain ischemia (6, 17, 18, 29, 54, 55, 69-72). An ischemic brain episode accelerates the onset of dementia by 10 years (73), and $10 \%$ of patients develop dementia soon after the first stroke, and $41 \%$ after a recurrent ischemic stroke $(6,74)$. In this chapter, we discuss the latest advances in postischemic brain neurodegeneration research, and highlight genes related to amyloid protein precursor (APP) processing and tau protein dysregulation, which further contribute to neuronal dysfunction and death, neurodegeneration, and underlie neurological deficits and cognitive impairment that lead to full-blown dementia.

\section{AMYLOID PROTEIN PRECURSOR PROCESSING GENES IN POST-ISCHEMIC BRAIN}

The basic phenomena associated with amyloid-mediated post-ischemic brain neurodegeneration are unclear. Below, we present the existing facts on the amyloidogenic metabolism of the amyloid protein precursor to amyloid following brain ischemia and reperfusion, which is related to the production and accumulation of amyloid in the brain. The presence of amyloid in serum and post-ischemic brain shed new light on the understanding of the role of amyloid in the development of post-ischemic brain neurodegeneration with full-blown Alzheimer's disease-type dementia.

\section{CA1 area of hippocampus}

The expression of APP gene in the CAl region of the hippocampus is decreased 2 days after ischemia but increased above the control values on days 7 and 30 
(Table 1) (75). The BACE1 ( $\beta$-secretase) gene increased within 2-7 days and decreased 30 days post-ischemia (Table 1) (75). The PSEN1 and 2 (presenilin 1 and 2) genes increased within 2-7 days and decreased after 30 days postischemia (Table 1) (75). Changes in the expression of the APP gene were statistically significant between 2 and 7,2 and 30, and 7 and 30 days after cerebral ischemia (75). Alterations in BACE1 gene expression were statistically significant between 2 and 7,2 and 30, and 7 and 30 days post-ischemia (75). Changes in PSEN1 gene expression were statistically significant between 2 and 30, and 7 and 30 days after ischemia (75). Alterations in PSEN2 gene expression were statistically significant between 2 and 7,2 and 30, and 7 and 30 days following cerebral ischemia (75).

\section{TABLE 1 Alzheimer's disease-associated genes in the CA1 area of hippocampus in post-ischemia}

\begin{tabular}{lcccccccc} 
& \multicolumn{1}{c}{ Genes } \\
\cline { 2 - 9 } Survival & APP & BACE1 & PSEN1 & PSEN2 & MAPT & BECN1 & BNIP3 & CASP3 \\
\hline 2 days & $\downarrow$ & $\uparrow \uparrow$ & $\uparrow$ & $\uparrow \uparrow$ & $\uparrow \uparrow$ & $\leftrightarrow$ & $\uparrow$ & $\uparrow$ \\
7 days & $\uparrow$ & $\uparrow$ & $\uparrow$ & $\uparrow$ & $\uparrow$ & $\leftrightarrow$ & $\leftrightarrow$ & $\uparrow$ \\
30 days & $\uparrow$ & $\downarrow$ & $\downarrow$ & $\downarrow$ & $\downarrow$ & $\leftrightarrow$ & $\leftrightarrow$ & $\downarrow$
\end{tabular}

Expression: $\uparrow$, increase; $\uparrow \uparrow$, increase; $\downarrow$, decrease; $\leftrightarrow$, oscillation around control values. Genes: APP, amyloid protein precursor; BACE1, $\beta$-secretase; BECN1, Beclin1; BNIP3, BCL2 interacting protein 3; CASP3-Caspase 3; MAPT, tau protein; PSEN1, presenilin 1; PSEN2, presenilin 2.

\section{CA3 area of hippocampus}

In the CA3 region of the hippocampus, 2 and 30 days after ischemia, the mean expression level of the APP gene was close to the control values (Table 2) (76). However, 7 days after ischemia, the expression of the APP gene was above the control values (76). Expression of the ADAM10 ( $\alpha$-secretase) gene was below control values at 2, 7 and 30 days after ischemia (Table 2) (76). Expression of the mean level of the BACE1 gene in the CA3 area decreased after 2-7 days, but increased above the control values 30 days post-ischemia (Table 2) (76). The PSEN1 gene increased within 2-7 days and oscillated around control values after 30 days post-ischemia. The expression of the PSEN2 gene after ischemia fluctuated around control values within 2 days, while on day 7 it was reduced, but on day 30 it was above the control values (Table 2) (76). Changes in the expression of the APP gene were statistically significant between 2 and 7 , and 7 and 30 days post-ischemia (76). Alterations in BACE1gene expression were statistically significant between 2 and 30 days after ischemia (76). Changes in PSEN1gene expression were statistically significant between 2 and 30, and 7 and 30 days following ischemia (76). Alterations in PSEN2 gene expression were statistically significant between 2 and 30, and 7 and 30 days after ischemia (76). 


\section{TABLE 2 Alzheimer's disease-associated genes in the CA3 area of hippocampus in post-ischemia}

\begin{tabular}{lccccccccc} 
& \multicolumn{10}{c}{ Genes } \\
\cline { 2 - 9 } Survival & APP & ADAM10 & BACE1 & PSEN1 & PSEN2 & MAPT & BECN1 & BNIP3 & CASP3 \\
\hline 2 days & $\leftrightarrow$ & $\downarrow$ & $\downarrow$ & $\uparrow$ & $\leftrightarrow$ & $\leftrightarrow$ & $\leftrightarrow$ & $\downarrow$ & $\downarrow$ \\
7 days & $\uparrow$ & $\downarrow$ & $\downarrow$ & $\uparrow$ & $\downarrow$ & $\uparrow$ & $\downarrow$ & $\downarrow$ & $\uparrow$ \\
30 days & $\leftrightarrow$ & $\downarrow$ & $\uparrow$ & $\leftrightarrow$ & $\uparrow$ & $\uparrow$ & $\uparrow$ & $\downarrow$ & $\uparrow$
\end{tabular}

Expression: $\uparrow$ increase; $\downarrow$, decrease; $\leftrightarrow$, oscillation around control values. Genes: APP, amyloid protein precursor; ADAM10, $\alpha$-secretase; BACE1, $\beta$-secretase; BECN1, Beclin1; BNIP3, BCL2 interacting protein 3; CASP3-Caspase 3; MAPT, tau protein; PSEN1, presenilin 1; PSEN2, presenilin 2.

\section{Medial temporal cortex}

Expression of the mean level of the APP gene in the medial temporal cortex decreased after 2 days, but increased above the control values 7 and 30 days post-ischemia (Table 3) (77). The expression of the BACE1 gene was above control values within 2 days, and in 7-30 days post-ischemia, fluctuated around control values (Table 3) (77). Expression of the PSEN1 gene fluctuated around control values 2, 7 and 30 days post-ischemia (Table 3) (78). The highest expression of the PSEN2 gene was noted on the second day post-ischemia, whereas on days 7-30 the expression of this gene was within the control values (Table 3) (78). Changes in expression of the APP gene were statistically significant between 2 and 7 , and 2 and 30 days post-ischemia (77). Alterations in BACE1 gene expression were statistically significant between 2 and 7 , and 2 and 30 days following ischemia (77). Changes in PSEN1 gene were never statistically significant during the post-ischemic period (78) whereas changes in PSEN2 gene expression were statistically significant between 2 and 7 , and 2 and 30 days (78).

\section{TABLE 3 Alzheimer's disease-associated genes in the medial temporal cortex in post-ischemia}

\begin{tabular}{lccccccc} 
& \multicolumn{7}{c}{ Genes } \\
\cline { 2 - 7 } Survival & APP & BACE1 & PSEN1 & PSEN2 & BECN1 & BNIP3 & CASP3 \\
\hline 2 days & $\downarrow$ & $\uparrow \uparrow$ & $\leftrightarrow$ & $\uparrow \uparrow$ & $\uparrow \uparrow$ & $\downarrow \downarrow$ & $\downarrow \downarrow$ \\
7 days & $\uparrow$ & $\leftrightarrow$ & $\leftrightarrow$ & $\leftrightarrow$ & $\uparrow$ & $\uparrow \uparrow$ & $\uparrow \uparrow$ \\
30 days & $\uparrow$ & $\leftrightarrow$ & $\leftrightarrow$ & $\leftrightarrow$ & $\uparrow$ & $\leftrightarrow$ & $\uparrow$
\end{tabular}

Expression: $\uparrow$, increase; $\uparrow \uparrow$, increase; $\downarrow$, decrease; $\downarrow \downarrow$, decrease; $\leftrightarrow$, oscillation around control values. Genes: APP, amyloid protein precursor; BACE1, $\beta$-secretase; BECN1, Beclin 1; BNIP3, BCL2 interacting protein 3; CASP3-Caspase 3; PSEN1, presenilin 1; PSEN2, presenilin 2. 


\section{TAU PROTEIN GENE IN POST-ISCHEMIC BRAIN}

The tau protein is a microtubule-related protein expressed in the brain, especially in unmyelinated cortical axons. It is mainly noted in neurons and to a lesser extent in neuroglial cells. In neurons, it plays a key role in structural stabilization and the formation of the neuronal cytoskeleton. Elevated tau protein levels have been detected in the brain and blood following ischemia-reperfusion. The mechanisms underlying tau protein dysfunction that influence the development of post-ischemic brain neurodegeneration have not been definitively elucidated. In this analysis, we indicate that both the ischemia itself and the permeability of the blood-brain barrier after ischemia influence the behavior of the tau protein. Tau protein dysfunction starts with hyperphosphorylation which results in the development of paired helical filaments, neurofibrillary tangle-like, and ultimately neurofibrillary tangles that are hazardous to microtubule activity, especially in neurons, and are involved in the development of irreversible post-ischemic brain neuropathology with the Alzheimer's disease phenotype and genotype.

\section{CA1 area of hippocampus}

Expression of the mean level of the tau protein gene (MAPT) in the CAl region increased in 2-7 days, but decreased below the control values 30 days after ischemia (Table 1) (79). The statistical significance of alterations in MAPT gene expression following ischemia-reperfusion was between 2 and 7 , and 2 and 30 days post-ischemia (79).

\section{CA3 area of hippocampus}

In the CA3 area of the hippocampus, the mean level of the MAPT gene expression oscillated around control values within 2 days, but 7-30 days post-ischemia, the expression was above control values (Table 2) (76). The statistical significance of changes following ischemia-reperfusion brain injury was between 2 and 7 , and 2 and 30 days (76).

\section{GENES INVOLVED IN THE DEATH OF NEURONS IN POST- ISCHEMIC BRAIN}

As aging is one of the risk factors for ischemic stroke, aging mechanisms are believed to be important in stroke development and post-stroke neurodegeneration. Post-ischemic brain neurodegeneration appears to promote the development of an irreversible Alzheimer's disease-like neuropathology through neuronal death, neuroinflammation, white matter damage, and hippocampal and brain atrophy, probably caused by genes responsible for neuronal death in Alzheimer's disease. Current research indicates that cerebral ischemia leads to Alzheimer's 
disease-type neurodegeneration and many end events such as dysregulation of genes that are involved in neuronal death in different brain structures at different times and with varying severity. Understanding the underlying pathological pathways causing proteomic and genomic changes characteristic of Alzheimer's disease and cerebral ischemia will help elucidate the development of neurodegenerative diseases with dementia and develop treatments for them.

\section{CA1 area of hippocampus}

Expression of the mean level of the BECN1 gene (autophagy-related gene) in the CAl area of the hippocampus fluctuated around control values on days 2, 7, and 30 after ischemia (Table 1) (80). The BNIP3 gene (mitophagy-related gene) expression in the CAl region increased within 2 days of ischemia, but from 7 to 30 days, oscillated around control values (Table 1) (80). Increased expression of the caspase- 3 gene was observed between 2 and 7 days but decreased on day 30 (Table 1) (80). Alterations in BECN1 gene expression were never statistically significant post-ischemia (80). Significant changes in BNIP3 gene expression in the CAl area was noted between 2 and 7 , and 2 and 30 days in post-ischemic brain injury (80). Changes in expression of the caspase- 3 gene between 2 and 7,2 and 30 , and 7 and 30 days post-ischemia were statistically significant (80).

\section{CA3 area of hippocampus}

The mean level of BECN1 gene expression in the CA3 area of the hippocampus oscillated around control values within 2 days, in 7 days it was below the control value, and on day 30, it increased above control values (Table 2) (81). The expression of the BNIP3 gene was below control values at all stated times (Table 2) (81). Caspase- 3 gene expression was below control values within 2 days and increased between 7 and 30 days. (Table 2) (81). Changes in BECN1 gene expression were statistically significant between 2 and 7,2 and 30, and 7 and 30 days after ischemia (81). Changes in BNIP3 gene were not statistically significant (81). Alterations in caspase- 3 gene expression were statistically significant between 2 and 7 , and 2 and 30 days post-ischemia (81).

\section{Medial temporal cortex}

The mean level of BECN1 gene expression was always increased in the medial temporal cortex after brain ischemia (Table 3) (82). Nevertheless, the expression of the BNIP3 gene decreased on day 2 , increased on day 7 , and reached a value similar to the controls on day 30 (Table 3) (82). Two days post-ischemia, the expression of caspase-3 gene decreased but it increased between days 7 and 30 (Table 3) (82). Changes in BECN1 gene were statistically significant between 2 and 30 days post-ischemia (82). Alterations of BNIP3 gene expression were statistically significant between 2 and 7 , and 2 and 30 days following brain ischemia injury (82). Statistically significant alterations in caspase- 3 gene expression were noted between 2 and 7 , and 2 and 30 days post-ischemia (82). 


\section{CONCLUSION}

Loss of neurons, with the accumulation of misfolded proteins in the form of amyloid plaques and neurofibrillary tangles, as well as neurological deficits with the development of full-blown dementia of the Alzheimer's disease-type are the main features of post-ischemic brain neurodegeneration (Figure 1). In this chapter, we present data of amyloid protein precursor, amyloid secretases, tau protein, autophagy, mitophagy and apoptosis-related genes induction post-ischemia, all of which play a key role in the development of post-ischemic brain neurodegeneration with the Alzheimer's disease phenotype and genotype. We presented the gene expression of the APP, ADAM10, BACE1, and PSEN1 and 2 in post-ischemic animals in the $\mathrm{CAl}$ and $\mathrm{CA} 3$ regions of the hippocampus and the medial temporal cortex. The data showed that experimental ischemic brain injury activates neuronal death in the hippocampus and medial temporal cortex in a manner dependent on amyloid production. A consequence of the above process is the accumulation of amyloid in the intra- and extracellular space and additional neuronal death due to amyloid neurotoxicity followed by post-ischemic general brain atrophy, which leads to the development of Alzheimer's disease-type dementia. This evidence suggests that post-ischemic amyloidogenic processing of the amyloid protein precursor, along with amyloid accumulation, play a key role in the acute and chronic death of CA1 and CA3 neurons in the hippocampus and medial temporal cortex. The formation of amyloid plaques in the hippocampus and medial temporal

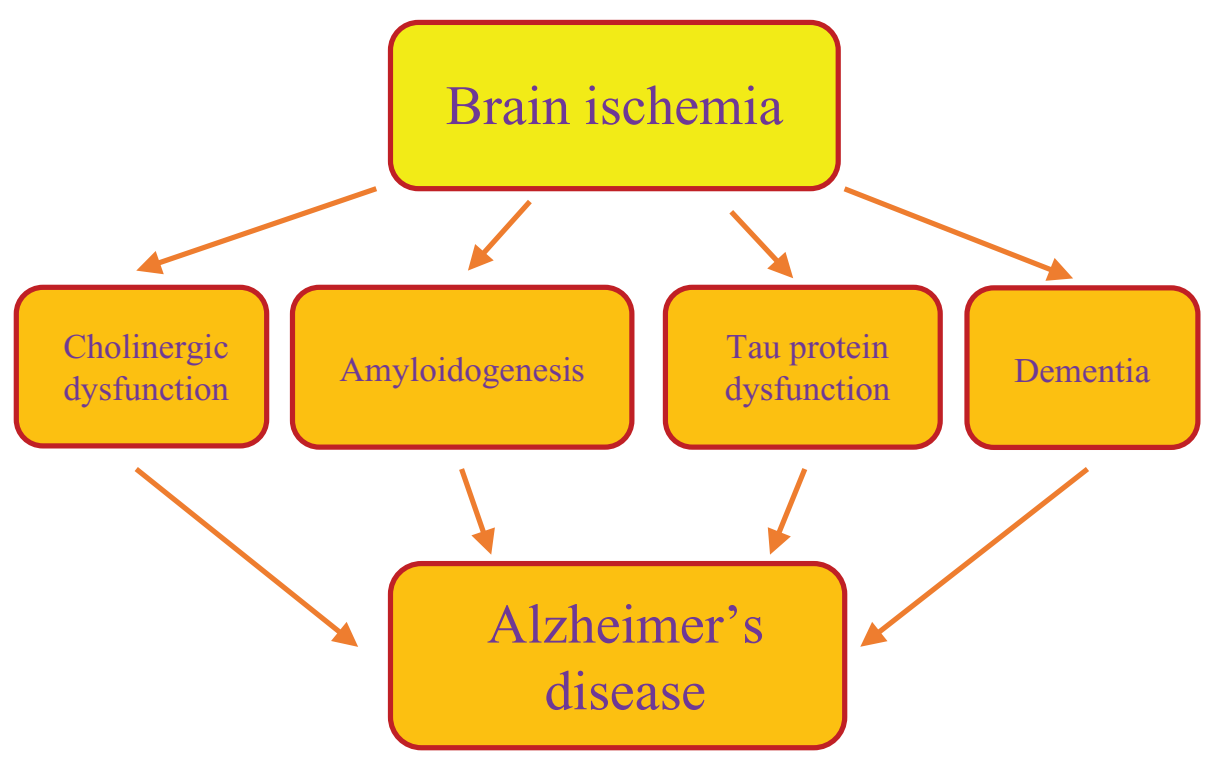

Figure 1. Relationship between cerebral ischemia and Alzheimer's Disease. Brain ischemia triggers various post-ischemic events including cholinergic dysfunction, amyloidogenesis, and tau protein dysfunction, eventually leading to full-blown dementia. These events have remarkable parallelism with Alzheimer's disease. 
cortex is highly likely to be due to increased production, increased plasma influx, and decreased clearance of amyloid from the brain parenchyma.

In addition, studies have shown that ischemia of the CAl and CA3 region of the hippocampus also affects the expression of the MAPT gene. It should be noted that ischemic overexpression of the MAPT gene during acute neuronal death in the CAl and CA3 region of the hippocampus was accompanied by dysregulation of the autophagy, mitophagy and apoptosis genes. The data show a correlation between increased caspase- 3 levels and the formation of neurofibrillary tangles. Post-ischemic overexpression of the MAPT gene indicates an increase in tau protein translation and subsequent increased hyperphosphorylation. Support for the above is elevated Cdk5 levels following ischemic brain injury, eventually leading to the development of neurofibrillary tangles. The above evidence indicates ischemic neuronal death in the hippocampus in a manner dependent on tau protein dysfunction.

Data presented in this chapter show that apoptotic neuronal death coincides with dysregulation of autophagy and mitophagy-related genes, suggesting the involvement of these genes in ischemic neuronal death in the hippocampus and medial temporal cortex. Caspase-3 is highly likely to break down baclin 1 to eliminate the cell survival provided by autophagy, which causes apoptosis to dominate. Caspase 3 enhances $\beta$-secretase activity, resulting in enhanced amyloidogenic processing of amyloid protein precursor to neurotoxic amyloid.

Finally, in line with data from literature, it can be concluded that focal and total brain ischemia-reperfusion triggers the processing of the amyloid protein precursor at both gene and protein levels and leads to the accumulation of neurotoxic amyloid in the parenchyma of the brain. An understanding of the postischemic differential expression of Alzheimer's disease-related genes in the hippocampus and medial temporal cortex, and the genes that contribute to neuronal death, amyloid production, and the development of neurofibrillary tangles, may be important in unraveling the etiology and future treatment of Alzheimer's disease (Figure 1).

The parallelism between post-ischemic brain neurodegeneration and Alzheimer's disease, at least at the molecular level, is remarkable (Figure 1). Ignoring scientifically validated experimental and clinical data on the links between brain ischemia and Alzheimer's disease will not only hamper proper understanding of the mechanism of both diseases, but also the development of causal treatments for post-ischemic neurodegeneration and Alzheimer's disease. Since the mere accumulation of amyloid and tau protein, as believed, may not lead to the development of Alzheimer's disease, further research is needed in this area, with particular attention to the role of ischemia. Thus, animal models of brain ischemia appear to be useful in determining the role of folding proteins and their genes in neurodegenerative processes such as post-ischemic brain neurodegeneration and Alzheimer's disease.

Acknowledgment: The authors acknowledge the financial support from the Mossakowski Medical Research Institute, Polish Academy of Sciences, Warsaw, Poland (T-3).

Conflict of Interest: The authors declare no potential conflicts of interest with respect to research, authorship, and/or publication of this chapter. 
Copyright and Permission Statement: To the best of our knowledge, the materials included in this chapter do not violate copyright laws. All original sources have been appropriately acknowledged and/or referenced. Where relevant, appropriate permissions have been obtained from the original copyright holder(s).

\section{REFERENCES}

1. Goulay R, Romo LM, Hol EM, Dijkhuizen RM. From stroke to dementia: a comprehensive review exposing tight interactions between stroke and amyloid- $\beta$ formation. Transl Stroke Res. 2020;11: 601-614. https://doi.org/10.1007/s12975-019-00755-2

2. Seshadri S, Wolf PA. Lifetime risk of stroke and dementia: current concepts, and estimates from the Framingham Study. Lancet Neurol. 2007;6:1106-1114. https://doi.org/10.1016/S1474-4422 (07)70291-0

3. Bejot Y, Daubail B, Giroud M. Epidemiology of stroke and transient ischemic attacks: Current knowledge and perspectives. Rev Neurol. 2016;172:59-68. https://doi.org/10.1016/j.neurol. 2015.07 .013

4. Pluta R, Ułamek-Kozioł M, Januszewski S, Czuczwar S. Amyloid pathology in the brain after ischemia. Folia Neuropathol. 2019;57:220-226. https://doi.org/10.5114/fn.2019.88450

5. Murphy SJX, Werring DJ. Stroke: causes and clinical features. Medicine. 2020;48:9. https://doi. org/10.1016/j.mpmed.2020.06.002

6. Lo JW, Crawford JD, Desmond DW, Godefroy O, Jokinen H, Mahinrad S, et al.Stroke and Cognition (STROKOG) Collaboration. Profile of and risk factors for post-stroke cognitive impairment in diverse ethno-regional groups. Neurology. 2019;93:e2257-e2271. https://doi.org/10.1212/ WNL.0000000000008612

7. Pluta, R. Brain Ischemia: Alzheimer's Disease Mechanisms; Nova, Science Publishers, Inc.: New York, NY, USA, 2019.

8. Sexton E, McLoughlin A, Williams DJ, Merriman NA, Donnelly N, Rohde D, et al. . Systematic review and meta-analysis of the prevalence of cognitive impairment no dementia in the first year post-stroke. Eur Stroke J. 2019;4:160-171. https://doi.org/10.1177/2396987318825484

9. Pluta R. From brain ischemia-reperfusion injury to possible sporadic Alzheimer's disease. Curr Neurovasc Res. 2004;1:441-453. https://doi.org/10.2174/1567202043361839

10. Pluta, R. Ischemia-Reperfusion Pathways in Alzheimer's Disease; Nova, Science Publishers, Inc.: New York, NY, USA, 2007a.

11. Pluta R. Role of ischemic blood-brain barrier on amyloid plaques development in Alzheimer's disease brain. Curr Neurovasc Res. 2007b;4:121-129. https://doi.org/10.2174/156720207780637207

12. Salminen A, Kauppinen A, Kaarniranta K. Hypoxia/ischemia activate processing of amyloid precursor protein: Impact of vascular dysfunction in the pathogenesis of Alzheimer's disease. J Neurochem. 2017;140:536-549. https://doi.org/10.1111/jnc.13932

13. Ahmad A, Patel V, Xiao J, Khan MM. The role of neurovascular system in neurodegenerative diseases. Mol Neurobiol. 2020;57:4373-4393. https://doi.org/10.1007/s12035-020-02023-z

14. Pluta, R. The role of apolipoprotein $\mathrm{E}$ in the deposition of $\beta$-amyloid peptide during ischemia-reperfusion brain injury. A model of early Alzheimer's disease. Ann NY Acad Sci. 2000; 903:324-334. https:// doi.org/10.1111/j.1749-6632.2000.tb06383.x

15. Pluta R, Ułamek M, Jabłonski M. Alzheimer's mechanisms in ischemic brain degeneration. Anat Rec. 2009;292:1863-1881. https://doi.org/10.1002/ar.21018

16. Pluta R, Januszewski S, Jabłoński M, Ułamek M. Factors in creepy delayed neuronal death in hippocampus following brain ischemia-reperfusion injury with long-term survival. Acta Neurochir. 2010;106(Suppl.):37-41. https://doi.org/10.1007/978-3-211-98811-4_5

17. Gemmell E, Bosomworth H, Allan L, Hall R, Khundakar A, Oakley AE, et al. Hippocampal neuronal atrophy and cognitive function in delayed poststroke and aging-related dementias. Stroke. 2012;43:808-814. https://doi.org/10.1161/STROKEAHA.111.636498 
18. Gemmell E, Tam E, Allan L, Hall R, Khundakar A, Oakley AE, et al. Neuron volumes in hippocampal subfields in delayed poststroke and aging-related dementias. J Neuropathol Exp Neurol. 2014;73:305-311. https://doi.org/10.1097/NEN.0000000000000054

19. Pluta R, Kida E, Lossinsky AS, Golabek AA, Mossakowski MJ, Wisniewski HM. Complete cerebral ischemia with short-term survival in rats induced by cardiac arrest. I. Extracellular accumulation of Alzheimer's $\beta$-amyloid protein precursor in the brain. Brain Res. 1994b;649:323-328. https://doi. org/10.1016/0006-8993(94)91081-2

20. Jendroska K, Poewe W, Daniel SE, Pluess J, Iwerssen-Schmidt H, Paulsen J, et al. Ischemic stress induces deposition of amyloid beta immunoreactivity in human brain. Acta Neuropathol. 1995;90:461-466. https://doi.org/10.1007/BF00294806

21. Wisniewski HM, Maslinska D. Beta-protein immunoreactivity in the human brain after cardiac arrest. Folia Neuropathol. 1996;34:65-71.

22. Jendroska K, Hoffmann OM, Patt S. Amyloid $\beta$ peptide and precursor protein (APP) in mild and severe brain ischemia. Ann NY Acad Sci. 1997;826:401-405. https://doi.org/10.1111/j.1749-6632.1997. tb48492.x

23. Pluta R, Barcikowska M, Dębicki G, Ryba M, Januszewski S. Changes in amyloid precursor protein and apolipoprotein $\mathrm{E}$ immunoreactivity following ischemic brain injury in rat with long-term survival: influence of idebenone treatment. Neurosci Lett. 1997a;232:95-98. https://doi.org/10.1016/ S0304-3940(97)00571-5

24. Pluta R, Barcikowska M, Mossakowski MJ, Zelman I. Cerebral accumulation of beta-amyloid following ischemic brain injury with long-term survival. Acta Neurochir. 1998;71(Suppl.):206-208. https:// doi.org/10.1007/978-3-7091-6475-4_59

25. Pluta R. Glial expression of the $\beta$-amyloid peptide in cardiac arrest. J Neurol Sci. 2002a;203-204: 277-280. https://doi.org/10.1016/S0022-510X(02)00305-2

26. Pluta R. Astroglial expression of the beta-amyloid in ischemia-reperfusion brain injury. Ann NY Acad Sci. 2002b;977:102-108. https://doi.org/10.1111/j.1749-6632.2002.tb04803.x

27. Van Groen T, Puurunen K, Maki HM, Sivenius J, Jolkkonen J. Transformation of diffuse beta-amyloid precursor protein and beta-amyloid deposits to plaques in the thalamus after transient occlusion of the middle cerebral artery in rats. Stroke. 2005;36:1551-1556. https://doi.org/10.1161/01. STR.0000169933.88903.cf

28. Qi J, Wu H, Yang Y, Wand D, Chen Y, Gu Y, et al. Cerebral ischemia and Alzheimer's disease: the expression of amyloid- $\beta$ and apolipoprotein $E$ in human hippocampus. J Alzheimers Dis. 2007;12:335-341. https://doi.org/10.3233/JAD-2007-12406

29. Akinyemi RO, Allan LM, Oakley A, Kalaria RN. Hippocampal neurodegenerative pathology in poststroke dementia compared to other dementias and aging controls. Front Neurosci. 2017;11:717. https://doi.org/10.3389/fnins.2017.00717

30. Schiefecker AJ, Putzer G, Braun P, Martini J, Strapazzon G, Antunes AP, et al. Total tau-protein as investigated by cerebral microdialysis increases in hypothermic cardiac arrest: A pig study. Ther Hypothermia Temp Manag. 2021; 11:28-34. https://doi.org/10.1089/ther.2020.0016

31. Wen Y, Yang S, Liu R, Simpkins JW. Transient cerebral ischemia induces site-specific hyperphosphorylation of tau protein. Brain Res. 2004a;1022:30-38. https://doi.org/10.1016/j.brainres.2004.05.106

32. Khan S, Yuldasheva NY, Batten TFC, Pickles AR, Kellett KAB, Saha S. Tau pathology and neurochemical changes associated with memory dysfunction in an optimized murine model of global cerebral ischaemia - A potential model for vascular dementia? Neurochem Int. 2018;118:134-144. https://doi. org/10.1016/j.neuint.2018.04.004

33. Wen Y, Yang S, Liu R, Brun-Zinkernagel AM, Koulen P, Simpkins JW. Transient cerebral ischemia induces aberrant neuronal cell cycle re-entry and Alzheimer's disease-like tauopathy in female rats. J Biol Chem. 2004b;279:22684-22692. https://doi.org/10.1074/jbc.M311768200

34. Wen Y, Yang SH, Liu R, Perez EJ, Brun-Ziukemagel AM, Koulen P, et al. Cdk5 is involved in NFT-like tauopathy induced by transient cerebral ischemia in female rats. Biochim Biophys Acta. 2007;1772:473-483. https://doi.org/10.1016/j.bbadis.2006.10.011

35. Kato T, Hirano A, Katagiri T, Sasaki H, Yamada S. Neurofibrillary tangle formation in the nucleus basalis of Meynert ipsilateral to a massive cerebral infarct. Ann Neurol. 1988;23:620-623. https://doi. org/10.1002/ana.410230617 
36. Hatsuta H, Takao M, Nogami A, Uchino A, Sumikura H, Takata T, et al. Tau and TDP-43 accumulation of the basal nucleus of Meynert in individuals with cerebral lobar infarcts or hemorrhage. Acta Neuropathol Commun. 2019;7:49. https://doi.org/10.1186/s40478-019-0700-z

37. Pluta R, Lossinsky AS, Wisniewski HM, Mossakowski MJ. Early blood-brain barrier changes in the rat following transient complete cerebral ischemia induced by cardiac arrest. Brain Res. 1994a;633: 41-52. https://doi.org/10.1016/0006-8993(94)91520-2

38. Pluta R. Blood-brain barrier dysfunction and amyloid precursor protein accumulation in microvascular compartment following ischemia-reperfusion brain injury with 1-year survival. Acta Neurochir. 2003;86(Suppl.):117-122. https://doi.org/10.1007/978-3-7091-0651-8_26

39. Pluta R. Pathological opening of the blood-brain barrier to horseradish peroxidase and amyloid precursor protein following ischemia-reperfusion brain injury. Chemotherapy. 2005;51:223-226. https://doi.org/10.1159/000086924

40. Pluta R, Ułamek M, Januszewski S. Micro-blood-brain barrier openings and cytotoxic fragments of amyloid precursor protein accumulation in white matter after ischemic brain injury in long-lived rats. Acta Neurochir. 2006;96(Suppl.):267-271. https://doi.org/10.1007/3-211-30714-1_57

41. Pluta R, Januszewski S, Ułamek M. Ischemic blood-brain barrier and amyloid in white matter as etiological factors in leukoaraiosis. Acta Neurochir. 2008;102(Suppl.):353-356. https://doi. org/10.1007/978-3-211-85578-2_67

42. Pluta R, Barcikowska M, Januszewski S, Misicka A, Lipkowski AW. Evidence of blood-brain barrier permeability/leakage for circulating human Alzheimer's $\beta$-amyloid-(1-42)-peptide. Neuroreport. 1996;7:1261-1265. https://doi.org/10.1097/00001756-199605170-00008

43. Pluta R, Misicka A, Januszewski J, Barcikowska M, Lipkowski AW. Transport of human $\beta$-amyloid peptide through the rat blood-brain barrier after global cerebral ischemia. Acta Neurochir. 1997b;70(Suppl.):247-249. https://doi.org/10.1007/978-3-7091-6837-0_76

44. Pluta R, Barcikowska M, Misicka A, Lipkowski AW, Spisacka S, Januszewski S. Ischemic rats as a model in the study of the neurobiological role of human $\beta$-amyloid peptide. Time-dependent disappearing diffuse amyloid plaques in brain. Neuroreport. 1999;10:3615-3619. https://doi. org/10.1097/00001756-199911260-00028

45. Pluta R, Misicka A, Barcikowska M, Spisacka S, Lipkowski AW, Januszewski S. Possible reverse transport of $\beta$-amyloid peptide across the blood-brain barrier. Acta Neurochir. 2000;76:73-77. https://doi. org/10.1007/978-3-7091-6346-7_15

46. Bitsch A, Horn C, Kemmling Y, Seipelt M, Hellenbrand U, Stiefel M, et al. Serum tau protein level as a marker of axonal damage in acute ischemic stroke. Eur Neurol. 2002;47:45-51. https://doi. org/10.1159/000047946

47. Lee PH, Bang OY, Hwang EM, Lee JS, Joo US, Mook-Jung I, et al. Circulating beta amyloid protein is elevated in patients with acute ischemic stroke. J Neural Transm. 2005;112: 1371-1379. https://doi. org/10.1007/s00702-004-0274-0

48. Wunderlich MT, Lins H, Skalej M, Wallesch CW, Goertler M. Neuron-specific enolase and tau protein as neurobiochemical markers of neuronal damage are related to early clinical course and longterm outcome in acute ischemic stroke. Clin Neurol Neurosurg. 2006;108:558-563. https://doi. org/10.1016/j.clineuro.2005.12.006

49. Kurzepa J, Bielewicz J, Grabarska A, Stelmasiak Z, Stryjecka-Zimmer M, Bartosik-Psujek H. Matrix metalloproteinase- 9 contributes to the increase of tau protein in serum during acute ischemic stroke. J Clin Neurosci. 2010;17:997-999. https://doi.org/10.1016/j.jocn.2010.01.005

50. Bielewicz J, Kurzepa J, Czekajska-Chehab E, Stelmasiak Z, Bartosik-Psujek H. Does serum tau protein predict the outcome of patients with ischemic stroke? J Mol Neurosci. 2011;43:241-245. https://doi. org/10.1007/s12031-010-9403-4

51. Mörtberg E, Zetterberg H, Nordmark J, Blennow K, Catry C, Decraemer H, et al. Plasma tau protein in comatose patients after cardiac arrest treated with therapeutic hypothermia. Acta Anaesthesiol Scand. 2011;55:1132-1138. https://doi.org/10.1111/j.1399-6576.2011.02505.x

52. Zetterberg H, Mörtberg E, Song L, Chang L, Provuncher GK, Patel PP, et al. Hypoxia due to cardiac arrest induces a time-dependent increase in serum amyloid $\beta$ levels in humans. PLoS One. 2011;6:e28263. https://doi.org/10.1371/journal.pone.0028263 
53. Randall J, Mörtberg E, Provuncher GK, Fournier DR, Duffy DC, Rubertsson S, et al. Tau proteins in serum predict neurological outcome after hypoxic brain injury from cardiac arrest: Results of a pilot study. Resuscitation. 2013;84: 351-356. https://doi.org/10.1016/j.resuscitation.2012.07.027

54. Liu W, Wong A, Au L, Yang J, Wang Z, Leung EY, et al. Influence of amyloid-beta on cognitive decline after stroke/transient ischemic attack: Three-year longitudinal study. Stroke. 2015a;46:3074-3080. https://doi.org/10.1161/STROKEAHA.115.010449

55. Liu YH, Cao HY, Wang YR, Jiao SS, Bu XL, Zeng F, et al. A $\beta$ is predictive for short-term neurological deficits after acute ischemic stroke. Neurotox Res. 2015b;27:292-299. https://doi.org/10.1007/ s12640-015-9518-z

56. Lasek-Bal A, Jedrzejowska-Szypulka H, Rozycka J, Bal W, Kowalczyk A, Holecki M, et al. The presence of tau protein in blood as a potential prognostic factor in stroke patients. J Physiol Pharmacol. 2016;67:691-696.

57. De Vos A, Bjerke M, Brouns R, De Roeck N, Jacobs D, Van den Abbeele L, et al. Neurogranin and tau in cerebrospinal fluid and plasma of patients with acute ischemic stroke. BMC Neurol. 2017;17:170. https://doi.org/10.1186/s12883-017-0945-8

58. Gotz J, Bodea LG, Goedert M. Rodent models for Alzheimer disease. Nat Rev Neurosci. 2018;19: 583-598. https://doi.org/10.1038/s41583-018-0054-8

59. Onatsu J, Vanninen R, JÄkÄlÄ P, Mustonen P, Pulkki K, Korhonen M, et al. Tau, S100B and NSE as blood biomarkers in acute cerebrovascular events. In Vivo. 2020;34:2577-2586. https://doi. org/10.21873/invivo. 12075

60. Pluta R, Salinska E, Puka M, Stafiej A, Łazarewicz JW. Early changes in extracellular amino acids and calcium concentrations in rabbit hippocampus following complete 15-min cerebral ischemia. Resuscitation. 1988;16:193-210. https://doi.org/10.1016/0300-9572(88)90046-9

61. Sekeljic V, Bataveljic D, Stamenkovic S, Ułamek M, Jabłonski M, Radenovic L, et al. Cellular markers of neuroinflammation and neurogenesis after ischemic brain injury in the long-term survival rat model. Brain Struct Funct. 2012;217:411-420. https://doi.org/10.1007/s00429-011-0336-7

62. Radenovic L, Nenadic M, Ułamek-Kozioł M, Januszewski S, Czuczwar SJ, Andjus PR, et al. Heterogeneity in brain distribution of activated microglia and astrocytes in a rat ischemic model of Alzheimer's disease after 2 years of survival. Aging (Albany NY). 2020;12:12251-12267. https://doi. org/10.18632/aging.103411

63. Hecht M, Kramer LM, von Arnim CAF, Otto M, Thal DR. Capillary cerebral amyloid angiopathy in Alzheimer's disease: association with allocortical/hippocampal microinfarcts and cognitive decline. Acta Neuropathol. 2018;135:681-694. https://doi.org/10.1007/s00401-018-1834-y

64. Wisniewski HM, Pluta R, Lossinsky AS, Mossakowski MJ. Ultrastructural studies of cerebral vascular spasm after cardiac arrest-related global cerebral ischemia in rats. Acta Neuropathol. 1995;90: 432-440. https://doi.org/10.1007/BF00294802

65. Yuan Y, Shan X, Men W, Zhai H, Qiao X, Geng L, et al. The effect of crocin on memory, hippocampal acetylcholine level, and apoptosis in a rat model of cerebral ischemia. Biomed Pharmacother. 2020;130:110543. https://doi.org/10.1016/j.biopha.2020.110543

66. Jabłonski M, Maciejewski R, Januszewski S, Ułamek M, Pluta, R. One year follow up in ischemic brain injury and the role of Alzheimer factors. Physiol Res. 2011;60 (Suppl. 1): 113-119. https://doi. org/10.33549/physiolres.932186

67. Ułamek-Kozioł, M.; Czuczwar, S.J.; Januszewski, S.; Pluta, R. Substantiation for the use of curcumin during the development of neurodegeneration after brain ischemia. Int J Mol Sci. 2020;21:517. https://doi.org/10.3390/ijms21020517

68. Hossmann KA, Schmidt-Kastner R, Ophoff BG. Recovery of integrative central nervous function after one hour global cerebro-circulatory arrest in normothermic cat. J Neurol Sci. 1987;77:305-320. https://doi.org/10.1016/0022-510X(87)90130-4

69. De la Tremblaye PB, Plamondon H. Impaired conditioned emotional response and object recognition are concomitant to neuronal damage in the amygdale and perirhinal cortex in middle-aged ischemic rats. Behav Brain Res. 2011;219:227-233. https://doi.org/10.1016/j.bbr.2011.01.009

70. Kiryk A, Pluta R, Figiel I, Mikosz M, Ułamek M, Niewiadomska G, et al. Transient brain ischemia due to cardiac arrest causes irreversible long-lasting cognitive injury. Behav Brain Res. 2011;219:1-7. https://doi.org/10.1016/j.bbr.2010.12.004 
71. Li J, Wang YJ, Zhang M, Fang CQ, Zhou HD. Cerebral ischemia aggravates cognitive impairment in a rat model of Alzheimer's disease. Life Sci. 2011;89:86-92. https://doi.org/10.1016/j.lfs.2011.04.024

72. Cohan CH, Neumann JT, Dave KR, Alekseyenko A, Binkert M, Stransky K, et al. Effect of cardiac arrest on cognitive impairment and hippocampal plasticity in middle-aged rats. PLoS One. 2015;10:e0124918. https://doi.org/10.1371/journal.pone.0124918

73. De Ronchi D, Palmer K, Pioggiosi P, Atti AR, Berardi D, Ferrari B, et al. The combined effect of age, education, and stroke on dementia and cognitive impairment no dementia in the elderly. Dement Geriatr Cogn Disord. 2007;24:266-273. https://doi.org/10.1159/000107102

74. Pendlebury ST, Rothwell PM. Prevalence, incidence, and factors associated with pre-stroke and poststroke dementia: a systematic review and metaanalysis. Lancet Neurol. 2009;8: 1006-1018. https:// doi.org/10.1016/S1474-4422(09)70236-4

75. Kocki J, Ułamek-Kozioł M, Bogucka-Kocka A, Januszewski S, Jabłoński M, Gil-Kulik P, et al. Dysregulation of amyloid precursor protein, $\beta$-secretase, presenilin 1 and 2 genes in the rat selectively vulnerable CAl subfield of hippocampus following transient global brain ischemia. J Alzheimers Dis. 2015;47:1047-1056. https://doi.org/10.3233/JAD-150299

76. Pluta R, Ułamek-Kozioł M, Kocki J, Bogucki J, Januszewski S, Bogucka-Kocka A, et al. . Expression of the tau protein and amyloid protein precursor processing genes in the CA3 area of the hippocampus in the ischemic model of Alzheimer's disease in the rat. Mol Neurobiol. 2020;57:1281-1290. https:// doi.org/10.1007/s12035-019-01799-z

77. Pluta R, Kocki J, Ułamek-Kozioł M, Petniak A, Gil-Kulik P, Januszewski S, et al. Discrepancy in expression of $\beta$-secretase and amyloid- $\beta$ protein precursor in Alzheimer-related genes in the rat medial temporal lobe cortex following transient global brain ischemia. J Alzheimers Dis. 2016a;51:1023-1031. https://doi.org/10.3233/JAD-151102

78. Pluta R, Kocki J, Ułamek-Kozioł M, Bogucka-Kocka A, Gil-Kulik P, Januszewski S, et al. Alzheimerassociated presenilin 2 gene is dysregulated in rat medial temporal lobe cortex after complete brain ischemia due to cardiac arrest. Pharmacol Rep. 2016b;68:155-161. https://doi.org/10.1016/j. pharep.2015.08.002

79. Pluta R, Bogucka-Kocka A, Ułamek-Kozioł M, Bogucki J, Kocki J. Czuczwar SJ. Ischemic tau protein gene induction as an additional key factor driving development of Alzheimer's phenotype changes in CAl area of hippocampus in an ischemic model of Alzheimer's disease. Pharmacol Rep. 2018;70: 881-884. https://doi.org/10.1016/j.pharep.2018.03.004

80. Ułamek-Kozioł M, Kocki J, Bogucka-Kocka A, Januszewski S, Bogucki J, CzuczwarSJ, et al. Autophagy, mitophagy and apoptotic gene changes in the hippocampal CAl area in a rat ischemic model of Alzheimer's disease. Pharmacol Rep. 2017;69:1289-1294. https://doi.org/10.1016/j. pharep.2017.07.015

81. Ułamek-Kozioł M, Czuczwar SJ, Kocki J, Januszewski S, Bogucki J, Bogucka-Kocka A, et al. Dysregulation of autophagy, mitophagy, and apoptosis genes in the CA3 region of the hippocampus in the ischemic model of Alzheimer's disease in the rat. J Alzheimers Dis. 2019;72:1279-1286. https:// doi.org/10.3233/JAD-190966

82. Ułamek-Kozioł M, Kocki J, Bogucka-Kocka A, Petniak A, Gil-Kulik P, Januszewski S, et al. Dysregulation of autophagy, mitophagy and apoptotic genes in the medial temporal lobe cortex in an ischemic model of Alzheimer's disease. J Alzheimers Dis. 2016;54:113-121. https://doi.org/10.3233/ JAD-160387 